\title{
UNPUBLISHED VOTIVE STELA FROM THE EGYPTIAN MUSEUM IN CAIRO (CG34058)
}

\section{REHAB ELSHARNOUBY}

FACULTY OF TOURISM AND HOTELS, MANSOURA UNIVERSITY

\begin{abstract}
This paper is a publication of a votive stela preserved in the Egyptian Museum in Cairo under number CG 34058 (Plates 1, 2). According to the Museum Catalogue, the stela goes back to the New Kingdom, belongs to the so-called Nfr Mnw and was found in Abydos by A. Mariette. It is divided into three registers. The first one depicts the sun-disk with a single wing balanced by a single Wd 3 t eye. The second register represents the owner of the stela Nfr Mnw standing in an adoration position in front of God Osiris, who himself is sitting on his chair in front of an offering table. Whereas the third register portrays his family members: his wife and his three sons sitting in front of an offering table. The stela is in a good condition as well as its colors.
\end{abstract}

KEYwORDS: Abydos, Stela, Register, CG 34058, Mariette, Nfr Mnw.

\section{INTRODUCTION}

A stela is a piece of stone or wood that has multiple shapes. The roundtopped stela (as in this stela) is the dominant shape throughout the periods ${ }^{1}$. The owner of the stela is always represented with his family members, in front of an offering table, or in an adoration position in front of a god. The back of the stela (the verso) is usually polished; it is rarely left rough as in this stela. The verso, usually, does not bear any scenes or texts ${ }^{2}$.

The round-topped stelae ${ }^{3}$ appeared in the First Dynasty ${ }^{4}$, for example, the stela of King Jet (First Dynasty) conserved now in Louvre Museum under number E $11007^{5}$. There are several interpretations of the shape of the roundtopped stelae. One interpretation is that it may be influenced by the shape of

${ }^{1}$ R. Hölzl, "Stelae", in: D. Redford (ed.), The Oxford Encyclopedia of Ancient Egypt, III (Cairo, 2000), 319.

${ }^{2}$ M.L. Bierbrier, Historical Dictionary of Ancient Egypt, in: Historical Dictionaries of Ancient Civilizations and Historical Eras, I (Lanham, 1999), 155.

${ }^{3}$ K. Martin, "Stèle", in: LÄ VI (Wiesbaden, 1986), col. 1; R. Hölzl, Stelae, 285.

${ }^{4}$ G. Reisner, The Development of the Egyptian Tomb down to the Accession to the Cheops (Cambridge, 1936), 334-335; R. Hözl, Stelae, 285.

5 J. Vandier, Manuel d'Archéologie Égyptiennes, I (Paris, 1952), 724-726, Fig. 48. 
the tombs in Upper Egypt, which are topped by a small pyramid or are carved in the rock with vaulted chambers and arched doors ${ }^{6}$. Second interpretation is that it is maybe an imitation of the chapels of the primitive gods $^{7}$. Another religious interpretation indicates that the round summit of the stelae represents the prospect of the sky, symbolized by Goddess Nut (Goddess of the sky) who, sometimes, portrayed at the top of the stela as a curved woman leaning with her arms and legs on the ground, while her bended body occupies the top of the stela. As for its bottom, it incarnates the earth, embodied by God Geb (God of the earth). Its two sides represent the w3s scepter, symbolizing the pillars of the $\mathrm{sky}^{8}$. This shape continued throughout the Egyptian History until the end of the Greco-Roman Period ${ }^{9}$.

\section{DISCOVERY AND GENERAL DESCRIPTION}

The stela under our study is a painted round-topped rectangular votive stela ${ }^{10}$ (Plates 1,2), made of limestone and measures $37 \mathrm{~cm}$ height, 23.5 width. The stela, discovered by Mariette in Abydos, belongs to the so-called Nfr Mnw and goes back to the New Kingdom. The stela is currently exhibited in the Egyptian Museum in Cairo under number CG34058 and bears number 1066 in the catalogue of Mariette. The register of the Egyptian Museum recorded neither the exact excavation place nor the excavation date.

The stela is divided into three registers. A horizontal line separates the second and the third registers. Its edge is surrounded by a single line of shallow sunk-relief. The scenes are in high-relief while the hieroglyphic is in sunk-relief. The stela is in a good condition as well as its colors. Its surface is generally smooth except for little deterioration on its edges ${ }^{11}$. The back of the stela is left rough.

${ }^{6}$ G. Maspero, Guide to the Cairo Museum (Cairo, 1908), 85.

7 A. Badawy, "La stèle funéraire sous l'ancien empire: son origine et son fonctionnement", ASAE 48 (Le Caire, 1948), 228-232.

${ }^{8}$ K. Martin, Stèle, col. 1; W. Westendorf, "Altägyptische Darstellungen des Sonnenlaufes auf der Abscüssigen Himmelsbahn", MÄS 10 (Munich, 1966), 22, 65; R. Wilkinson, Reading Egyptian Art (London, 1992), 127.

سيريل الدريد، الفن الكصري القييم، مترجم، (القاهرة: الهيئة العامة للكتاب، 15 ، (1990

${ }^{10}$ Kings or individuals erect the votive stelae in sacred places or temples to express their idolization to the divinity. Often times, those kings or individuals were depicted in adoration positions pleading and praying to the divinity on the stela. Those stelae were usually discovered in small chapels in private houses.

${ }^{11} \mathrm{~A}$. Mariette, Catalogue Général des Monuments d'Abydos Découverts pendant les Fouilles de cette Ville (Paris, 1821-1881), 105, 34058. 


\section{The First Register (The Round Summit) (Plates 1, 2) (Figure1)}

The round summit of the studied stela (first register) directly connects to its second register without the usual horizontal dividing line, which distinguishes the Middle Kingdom and the Second Intermediate Period stelae ${ }^{12}$.

The first register is adorned with the winged sun-disk; but, in this stela, the left wing is depicted, whereas the artist has replaced the right wing of the sun-disk with the eye of Horus $\bar{\gtrless}(W \underline{d} 3 t)$ (Figure 1).

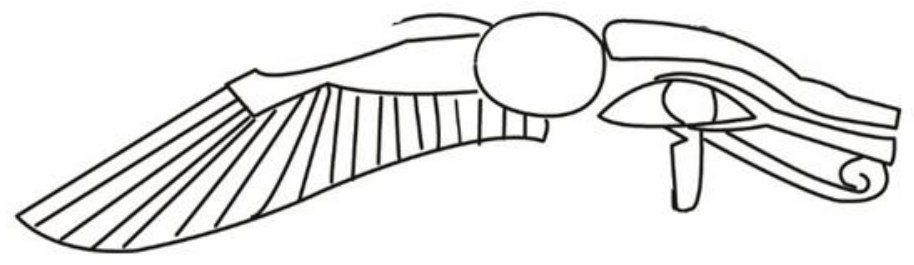

Figure 1. The First Register.

All the stelae of this type (sun-disk with a single wing balanced by a single 跑 $3 t$ eye) portray the individual in whose memory the stela was erected or who himself was the donor of it. Those stelae portray this individual making offering before one or more deities or deified kings. The single wing of the sun-disk is always represented as extending over the divinities, whereas the sacred eye is over the worshipper. The inventors of this style considered the wing of the sun-disk to be more appropriate as a symbol of protection for divinities than for mortals. The $W \underline{d} 3 t$ eye, worn often during life as an amulet and placed upon the body in the tomb, was a suitable emblem of the protection desired for the beloved dead in the underworld ${ }^{13}$.

The Ancient Egyptians called the winged sun-disk Great Sailor" or $\underset{11}{ }$ Bhdty "the Winged Sun-Disk" ${ }^{\circ}$, in addition to many other names. All these names reflect the nature of the Falcon God Horus as ntr-e3 "the Great God", $n b-p t$ "the Lord of the Sky",

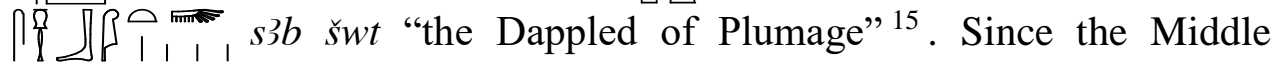
Kingdom, the depiction of the winged sun-disk was not only for adornment but it also had an important religious significance as it guarantees protection

${ }^{12} \mathrm{~A}$ horizontal line divides and separates the arched top from the body of the stela.

${ }^{13}$ L. Bull, "Two Egyptian Stelae of the XVIII Dynasty", Metropolitan Museum Arts, vol. 2, pt. 1 (Cairo, 1929), 76.

${ }^{14} \mathrm{~Wb}$ I, 179 [22], 180 [5].

15 مراد علام، قرص الثمس (المجنح) ذو الجناح الواحد وعين الودجات على قمم اللوحات، عالم الفراعنة، دراسات مقدمة تكريماً للأستاذة الدكتورة: تحفة حندوسة، العدد 37، الجزء الثاني (القاهرة، 2008)، 
for the deceased, and symbolizes the sunlight and the resurrection in the afterlife $^{16}$.

The winged sun-disk began to be depicted on the round summit of the individuals stelae since the end of the Twelfth Dynasty ${ }^{17}$. It symbolizes the spreading wings of God Horus in order to protect the deceased and to achieve his resurrection ${ }^{18}$. Note that this symbol transferred to the individuals' stelae since the end of the Middle Kingdom, but the depiction of the individual was coupled with the representation of the king and his name. Afterwards, the winged sun-disk lost its role as protector for the kings and started to be depicted over the individuals alone while praying in front of the divinities, to protect their relations with the divinities ${ }^{19}$.

The artist in the studied stela replaced the right wing of the sun-disk with the $W \underline{d} 3 t$ eye. It is a human eye surmounted by an eyebrow with a vertical excrescence from the bottom and a curved spiral arch extended to the back under the eye and it means the "intact" or the "well-being" 20 . It was considered a religious symbol and a decorative element as well. The first appearance of the $W \underline{d} 3 t$ eye was on the coffins and the false doors at the end of the Old Kingdom ${ }^{21}$. Later, it appeared on the stelae since the beginning of the Twelfth Dynasty as a protective symbol just for the kings; then, it became popular on the individuals' stelae ${ }^{22}$.

The researcher thinks that the depiction of the sun-disk with one wing beside the $W d$ st eye may indicate the completion of the eternal light during the day by the sun which is represented by the sun-disk and during the night by the moon which is represented by the eye of $W \underline{d} 3 t$. This point of view is

${ }^{16}$ D. Wildung, "Flügelsonne", in: LÄ II (Wiesbaden, 1977), col. 278; W. Westendorf, Altägyptische, 24.

${ }^{17}$ R. Hölzl, "Giebelfelddekoration von Stelen des Mittleren Reiches", Beiträge Zur Ägyptologie 10 (Wien, 1990), 55.

${ }^{18}$ R. Hölzl, "Round-Topped Stelae from Middle Kingdom to the Late Period, Remarks on the Decoration of the Lunettes", SCIE 1 (Wien, 1992), 288.

${ }^{19}$ A. Hermann, "Die Stelen der Thebanischen Felsgräber der 18. Dynastie", ÄF 11 (Glückstadt, 1940), 56.

20عائشة محمود عبد العال، لوحة إيري سبك بالمتحف المصري بالقاهرة رقم JE $91726 ،$ دراسات في علم المصريات لتكريم الدكتور : محمد عبدالحليم نور الدين، الجزء الأول (القاهرة، 2009)، باليعة

${ }^{21}$ A. Hermann, Stelen, 53.

22 عائشة محمود عبد العال، لوحات أفراد الدولة الوسطي (مجموهة المتحف المصري بالقاهرة)، رسالة ماجستير غير منشورة، كلية الآثار · جامعة القاهرة، (القاهرة، 1995)، 107. 
strengthened by the opinion of Ali Radwan that the $W \underline{d} 3 t$ eye represents for the deceased a major source of light (life). The winged sun-disk with the $W \underline{d} 3 t$ eye represents the daily cycle for the sun; i.e., the cycle of renewal and resurrection represented in the sunrise and the sunset of the sun ${ }^{23}$. Thus, portraying the sun-disk with the $W \underline{d} 3 t$ eye on this stela ensures for him protection, renewal and life as well as being an important element of lighting.

The stelae of this type (sun-disk with a single wing balanced by a single $W \underline{d} 3 t$ eye) go back to the Eighteenth Dynasty especially between the reigns of King Amenhotep I and King Amenhotep III. This opinion is based on the fact that most of the stelae of this type depict Kings Amenhotep I, II, III and Kings Thutmosis I, II, III, IV or their names as well as the individuals who worked during their reigns ${ }^{24}$. For example, the stelae exhibited in the Egyptian Museum in Cairo under numbers JE 38266 ${ }^{25}$, JE 34036, JE 34170, JE 34140, JE 34062, JE 34170; in Boston Museum under number 25.633; in the British Museum under number 512; in Louvre Museum under number C 202 and in the Ashmolean Museum under number $1893.173^{26}$.

The SECOND Register (Plates 1, 2) (Figure 2)

The owner of the stela Nfr Mnw stands in an adoration position in front of God Osiris, who himself is sitting on his chair in front of an offering table and holding the $w 3 s$ scepter (Figure 2).

The hieroglyphic texts are engraved in three different places in the second register:

1-In front of the owner of the stela: there are three vertical columns describing what he is doing.

2-In front of God Osiris: there is a horizontal line bearing the name of God Osiris and his title.

3-In front of the owner of the tomb's foot and under the offering table: there are two horizontal lines representing the name and the title of the tomb owner.

\footnotetext{
${ }^{23}$ A. Radwan, “The Stela Louvre C 211”, BACE 21 (Sydney, 2010), 107.

${ }^{24}$ L. Bull, Two Egyptian Stelae, 76-78.

${ }^{25}$ A. Gardiner, The Inscriptions of Sinai (London, 1955), 170.

${ }^{26}$ L. Bull, Two Egyptian Stelae, 77.
} 


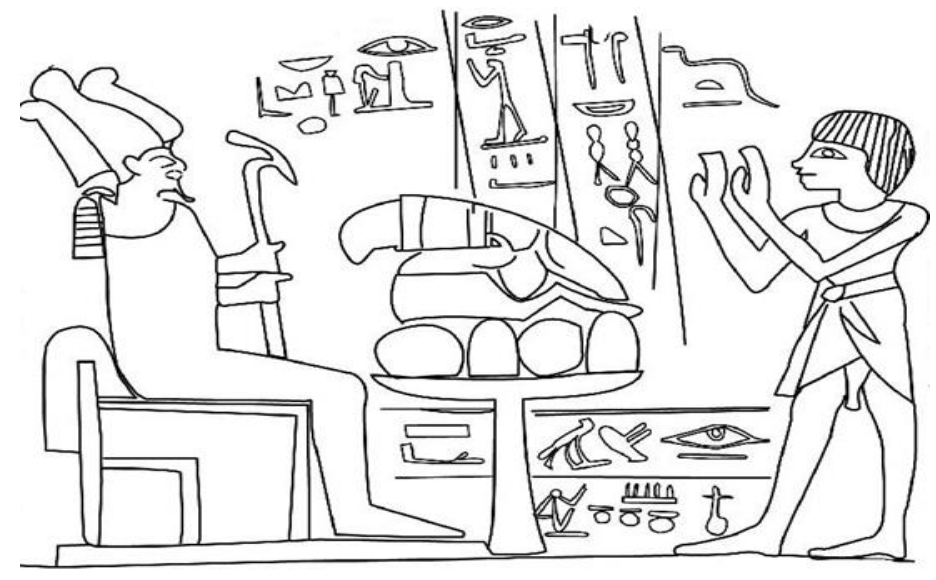

Figure 2.The Second Register

\section{The OWner Of The STela}

The owner of the stela Nfr Mnw is depicted standing on the right, facing left, on a line representing the ground; his both hands are raised in an adoration position to God Osiris. He is wearing a shoulder-length wig covering the ear and the back of his neck with overlapping locks, a short simple kilt held by a belt, a broad $w s h$ collar*27 and barefoot. $N f r-M n w$ skin is painted reddishbrown, while his costume and his collar are painted white. In front of his face, three vertical hieroglyphic columns that can be read as follows:

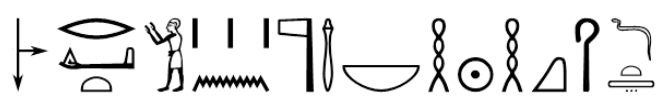

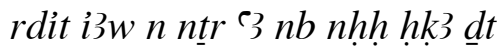

"Give praise to the Great God, Lord of Eternity, Ruler of Eternity"

One of the important observations deduced from this stela was that the artist carried out the painting after completing the etching of this inscription: the previous text etched in three vertical hieroglyphic slanted columns in sunkrelief, and, afterwards, the artist painted three straight red vertical lines, supposedly to correct the slanting of the inscribed text. Moreover, the direction of the signs of the word $\Delta ? h k$ is opposite to the direction of the

\footnotetext{
${ }^{27}$ This necklace was recognized since the Old Kingdom. Its name denotes the broad or the wide necklace. Men, women and gods wore this necklace. It was presented to the deceased to ensure eternal protection to him against his adversaries. It had a ritual value (not just an ornament) as it was depicted among the funeral offerings. For additional information, see T. Handoussa, "Le Collier Ousekh", SAK 9 (Hamburg, 1981), 146-147.
} 
rest of the signs of the text as well as the direction of the sign $\Delta \_d i$ in the word $\triangle$ rdit is opposite to the direction of the rest of the text (Figure $2)$.

A text of two horizontal lines appears in front of the foot of the owner of the stela $N$ fr Mnw and under the offering table as follows:

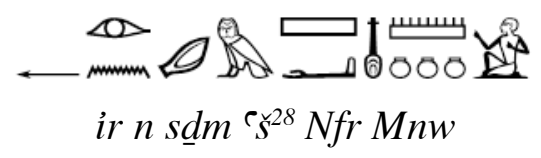

"Made for the servant Nfr Mnw"

The word $s \underline{d} m$ `̌ means "servant" but there is another translation to the word 'ک which is "call". In this case, the meaning of the sentence would convert to "made for the call listener $N f r M n w "$ (the call perhaps means the prayers $)^{29}$. In addition, since this text is written under the offering table, it may concern the table itself. In this case, the text can be read as follows:

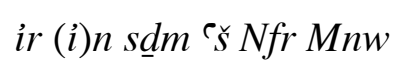

"Made (the Offerings) by the servant Nfr Mnw or the call listener Nfr

$$
M n w^{\prime \prime}
$$

The writer mistook in writing the word $\breve{s}$ before the letter $\mathrm{s}$ ?

From the previous text, it is clear that the name of the owner of the stela is Nfr Mnw. By tracing the first appearance of this name, it appeared during the Middle Kingdom. Its first appearance was in Lahun papyrus and continued during the New Kingdom. It has been written in several forms:

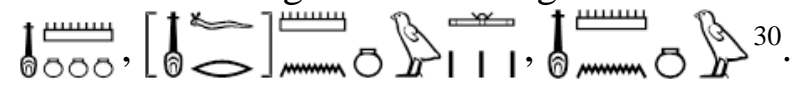

Nfr Mnw job title is not mentioned on this stela but its artistic features indicate that this person is a nobleman of the New Kingdom. The listener of the call is intended to hear prayers and funerary rituals that take place in front of the stela.

\footnotetext{
${ }^{28} \mathrm{~Wb} 4$, 389.13-390.4; R.O. Faulkner, Concise Dictionary of Middle Egyptian (Oxford, 1962), 259; H. Lesko, A Dictionary of Late Egyptian, III (Berkeley, 1987), 126.

${ }^{29} \mathrm{~Wb} 1,227,4-13$; R.O. Faulkner, Concise Dictionary, 48.

${ }^{30}$ H. Ranke, Die Ägyptischen Personennamen, Bd. 1: Verzeichnis der Namen (Glückstadt, 1935), 21, 196.
} 


\section{The OfFering TABLE}

Between the owner of the stela and God Osiris, there exists an offering table. It consists of a long base that takes the shape of a ply, while its upper part is flat, round and wide. This shape resembles a vessel, with a base less wide then its top in order to find a sufficient space for the offerings. A square hole on the bottom of the slab secures the single-footed table to its top end of the column. Traces of reddish-brown and blue pigments appear on the offering table and the offerings (Figure 2).

Offerings were one of the most important things that the Ancient Egyptian cared about and continued benefitting from. They were necessary for resurrection and immortality. Since food and drinks are the source of ability and movement during his life, it should give the deceased the ability to pursue all the activity aspects similar to what he did during his life ${ }^{31}$.

Our offering table means in hieroglyphic $\frac{0 \pi}{I} h 3 w t$. Its way of writing evolved from one period to another. form, which has been used during the Archaïc Period. Starting from the Fifth Dynasty, $h 3 w t$ was written with a determinative that consists of a table loaded with bread and different types of food $\$$ during the Middle and the New Kingdoms, it morphed to of $140 \frac{m}{\Delta}$. Offering tables generally have two distinct forms. One $\frac{\frac{0 \pi 0}{\Delta}}{\Delta}$ consists of stone or metal holder on which a slab is attached, as the one portrayed in our studied stela. The second

From the First Dynasty, the table $\triangle h 3 w t$ was used as an offering table for the deceased. Its role was limited as bread loaves holder. From the Fifth Dynasty, it became a holder of all kinds of food and offerings. It seems that this table loaded with food was originally an integral part of the Ancient Egyptian use in his daily life as a food table ${ }^{34}$.

\footnotetext{
${ }^{31}$ A.J. Spencer, Death in Ancient Egypt (New York, 1984), 48.

${ }^{32}$ A.O. Bolshakov, "Offering Tables", OEAE II (Oxford, 2001), 573; M. Mostafa, "Ntersuchungen zu Opfertafeln im Alten Reich", HÄB 17 (Hildesheim, 1982), 74.

${ }^{33}$ G. Maspero, Études de Mythologie et d'Archéologie Égyptiennes , IV (Paris, 1912), 356ff.

${ }^{34} \mathrm{P}$. Wilson, A Ptolemaïc Lexicon. A Lexicographical Study of the Ptolemaïc Texts in the Temple of Edfu (Leuven, 1997), 703.
} 
It was also called $h 3 w t^{35}$. Later, it became part of his funerary furniture that he preferred taking to his tomb to enjoy it in his other life. Since the middle of the First Dynasty, the deceased was always portrayed sitting in front of this offering table ${ }^{36}$. Its function continued as an offering holder until the end of the Pharaonic Period despite the change in its form from round to rectangular ${ }^{37}$.

The offering table depicted on the middle register of our stela contains many offerings stacked in four rows. The bottom one consists of four bread loaves: two rounded loaves and two conical loaves. The second row represents a bull thigh, while the third one consists of a piece of meat and a fish. The top row depicts a bunch of green onions. The religious significance of these offerings is as follows:

\section{- The BREAD}

Bread was a core nutrient of Ancient Egyptian traditional diet, which centers on bread and beer at almost each meal. Ancient Egyptian prepared bread using three different types of grain: barley, wheat and corn. The bread loaves discovered in tombs showed that most of the bread was made mainly of wheat, especially from ones provided to the deceased as offerings ${ }^{38}$. Bread, as an important offering, provides life to the deceased in the afterlife. Thus, it had many shapes, including the round and conical bread mentioned in this stela:

\section{- The Round BRead}

The bread is round and flat with barley as main ingredient. In addition to being as an offering, this bread was widely consumed in the daily diet, and was used as an ingredient in the beer brewing ${ }^{39}$. A Fourth Dynasty limestone stela, found in Saqqara, marked the first appearance of round bread. The offering lists of the Fifth and Sixth Dynasties mentioned the round bread

35 3الد الطلي، أهم موائد قرابين منطقة الصوة بمتحف هرية الرزنة، الدجلة العلمية إتحاد الآثاريين العرب 3، (القاهرة، 2002)، 37 (القال

${ }^{36} \mathrm{P}$. Wilson, Ptolemaïc Texts, 703.

${ }^{37}$ A.O. Bolshakov, Offering Tables, 574;

أحمد أنور عبد المهيمن، دراسة لموائد وأحواض القرابين بالمخزن المتحفي بالأشمونيين، رسالة ماجستير غير

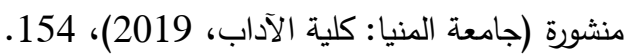

${ }^{38}$ D. Samuel, "Bread", in: D. Redford (ed.), The Oxford Encyclopedia of Ancient Egypt, I (Cairo, 2001), 196; 154 أحمد أنور عبد المهيم، دراسة لموائد القر ابين

${ }^{39}$ D. Samuel, Bread, 196. 
under the name $\square$ mm $p s n$ and sometimes as $\underset{\varnothing}{\stackrel{\square}{\square}} \mathrm{ps}^{40}$. Most of the offering lists of the Middle and New kingdoms and recordings of Madinet Habou Temple mention its name as psn associated with other bread names ${ }^{41}$. Its decoration evolved over the time. During the Old Kingdom, decorations were simple, just few fingerprints or a square in its middle. In the Middle Kingdom, decorations included small circles or dots. From the New Kingdom to the end of the Roman Period, its shapes and motifs increased ${ }^{42}$.

\section{- The Conical Bread}

The conical shape of bread appeared above the $\theta$ htp sign symbolizing the eternal hill that appeared from Noun, and from where God $R^{\top}$ shone, indicating the initial creation and consequently a symbol of rebirth ${ }^{43}$. Its name appeared in the offering lists during the Old and Middle Kingdoms, but transformed to a different determinative $X^{-\infty} \_s n s$ during the New Kingdom ${ }^{44}$. According to Selim Hassan, the name $̌ n s$ refers to the different shapes of the conical bread with various names ${ }^{45}$.

\section{- The Front Leg Of The Bull (The Bull Thigh)}

Numerous ceremonies for slaughtering the sacrificial animals existed in Ancient Egypt. The earliest portrayal of the slaughtering rituals and the presentation of the bull front leg $\curvearrowright h p \breve{s}$ as offering on the offering tables go back to the Old Kingdom. The portrayals continued on the walls of various tombs and temples during the Middle and New Kingdoms, and the Late Period ${ }^{46}$.

The Ancient Egyptian was interested in the bull as a symbol of strength and fertility. The slaughter of the bull and the slicing of its front leg helped reviving the deceased through giving him this animal part to ascend to

${ }^{40}$ T.G. James, The Mastaba of Khentika Called Ikhekhi (London, 1953), 62- 36;

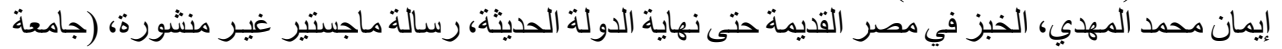

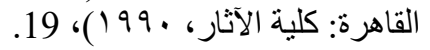

${ }^{41}$ H.H. Nelson, H. Leichter, A. Bollacher and S. Schott, Medinet Habu. 3: The Calendar, The Slaughterhouse, and Minor Records of Ramses III (Chicago, 1934), P1.152.

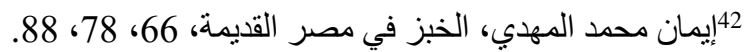

${ }^{43}$ H. Frankfort, Ancient Egyptian Religion (New York, 1949), 151-152.

إيمان محمد المهدي، الخبز في مصر H. Junker, Gîza, III (Wien-Leipzig, 1938), 101; القديمة، 28

${ }^{45}$ S. Hassan, Excavations at Giza, vol. VI, pt. II (Cairo, 1948), 324.

46 أيمن عبد الفتاح وزيري، دفهوم ومظاهر الخلود في مصر القديمة حتى نهاية عصر الدولة الحديثة، رسالة

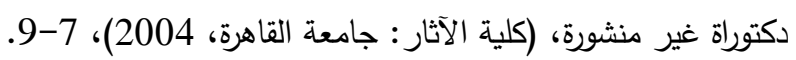


heaven similar to how Horus revived his father Osiris. The bull's front leg is considered the center of its strength. Therefore, its presentation to the deceased symbolizes the transmission of the strength within this leg to whom the offering is presented ${ }^{47}$. In general, Roths thinks that the $h p \check{s}$ shape resembles the Big Dipper constellation, which was believed to be the lodgment of souls of the dead. Therefore, the significance that the deceased will be reborn within the Big Dipper constellation, which was associated with eternity in the mind of the Ancient Egyptian $^{48}$.

\section{- The Green ONIONS}

Onions were known as 9 h $h \underline{d} w$. Green onions were served on offering tables mainly to God Sokar Osiris. Its appearance was associated with the dawn where the ground covered with white dew, where the white onion plant $h d w$ grew towards the light in order to restore life to Sokar. Sokar, then, transforms from the solid motionless state to a falcon soaring in the sky ${ }^{49}$.

\section{- God OSIRIS}

God Osiris is depicted to the left of the second register, facing right, in a human body, which is one of the most visible appearances on stelae. $\mathrm{He}$ wears an Atef crown: a crown surmounted by two feathers, two bent horns and two protector snakes. God Osiris, God Amun and the king in some occasions related to those deities, wore this same crown. Particularly, the Atef crown symbolizes justice, truth and completeness ${ }^{50}$. God Osiris is portrayed, as he most often is, swathed in the wrappings of a mummy. He wears the divine beard with the counterpoise behind, holding a $w 3 s$ scepter $^{51}$

${ }^{47}$ A.E. Weigall, “An Ancient Egyptian Funeral Ceremony”, JEA II (London, 1915), 10-12;

ماسيمولاني فرانشي، الفلك في مصر القديمة، تعريب: فاطمة فوزي- أنس إبراهيم- علاء شاهين، الطبعة الأولى، (القاهرة: المركز القومي للترجمة، 2015)،

${ }^{48}$ A.M., Roth, "Fingers, Stars, and the Opening of the Mouth: The Nature and Function of the ntrwj-Blades", JEA 79 (London, 1993), 70.

\footnotetext{
49 سيلفي كوفيل، قرابين الآلهة في مصر القديمة، تعريب: سهير لطف الله (القاهرة، 2010)، 86.

الروبير جاك تيبو، موسوعة الأساطير والرموز الفرعونية، تعريب: فاطمة عبد الله محمود، (القاهرة: المجلس لألس

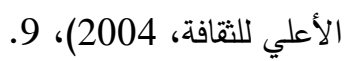

${ }^{51}$ For more information about the $w 3 s$ scepter, see: A. Radwan, "The Stela Louvre C 211", BACE 21 (Sydney, 2010), 110, note 4; A. Radwan, "Zur Stellung des Königs in der Zweiten Zwishenzeit", in: Festschrift Jürgen von Beckerath, HÄB 30 (Hildesheim, 1990), 230, note 33, fig. 2.
} 
with his both hands, and seated on his famous chair raised on a pedestal in front of the offering table (Figure 2). This chair appeared for the first time as a determinative in the Third Dynasty, and portrayed for the first time in inscriptions in the Fifth Dynasty ${ }^{52}$.

There are many interpretations of the name of $W$ sir and its pronunciation. Sometimes, it is Ws-ir or 3s-ir and means "a Lot of Eyes", "the Power and the Might of the Eyeball" or "the Throne Maker"53. In front of God Osiris head, there is a horizontal inscription, which reads as follows:

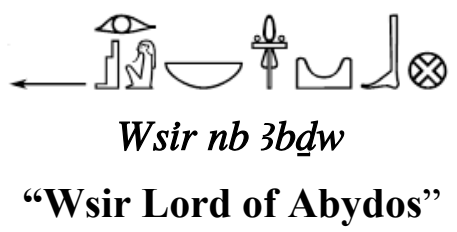

This is one of God Osiris titles. It has appeared since the Old Kingdom until the Greco-Roman Period ${ }^{54}$. God Osiris was considered one of the most popular deities in Ancient Egypt and Abydos* ${ }^{* 5}$. Abydos was the stronghold of his worship where people pilgrimaged to worship the Lord of the cemetery. Osiris was also the most portrayed god on the stelae for his religious status. Finally, God Osiris dress, crown and the outer part of his chair are in reddish-brown, while the middle part of the chair is in blue. God Osiris body is also in blue, which symbolizes the zenith of heavens and divine existence. The Nile flows in Egypt from the south to the north, and its water is not only blue but tends to be green and red. Therefore, the presence of Osiris (blue) was associated with the fertility (green) of the land of Egypt and its energy (red) ${ }^{56}$.

\footnotetext{
${ }^{52}$ K.P. Kuhlmann, "Der Throne im Alten Ägypten”, MDAIK 10 (Cairo-Berlin, 1977), $57 \mathrm{ff}$.

${ }^{53}$ A. Erman, "Zu Namen des Osiris”, ZÄS 46 (Leipzig, 1910), 92; Y. Muckiki, “On the Transliteration of the Name of Osiris", JEA 76 (London, 1990), 191-193.

${ }^{54} \mathrm{Ch}$. Leitz, Lexikon der Ägyptischen Götter und Götterbezeichnungen”, Bd. V (Leuven, 2002), 112, 562.
}

${ }^{55}$ Since the beginning of the Dynasties, Abydos was the most significant religious center for worshipping $W$ sir, which overwhelmingly dominated the city ancient God. Thus, the Ancient Egyptians considered Abydos the most significant place for pilgrimage and visiting, where they erected tombs and set up stelae, similar to the stela under study, to commemorate their legacy and presence in Osiris. For additional information, see: A. Badawy, "La stèle funéraire sous l'ancien empire", ASAE 48 (Le Caire, 1948), 238; J.W. Wegner, "Osiris", in: D. Redford (ed.), The Oxford Encyclopedia of Ancient Egypt, I (Cairo, 2001), 7.

$$
\text { كربير جاك تيبو، موسوعة الأساطير والرموز الفرعونية، } 44 .
$$


-THE THIRd Register (Plates 1, 2) (Figure 3)

A horizontal line, painted in black, separates the second and the third register. The third register shows the family members (wife and sons) of $N f r$ $M n w$ the owner of the stela. On the right, the eldest son $\mathrm{Hr} n \mathrm{nr} m n w$ is portrayed sitting on a lion-legged chair in front of both his mother, $\mathrm{Mwt} \mathrm{Hr}$ (the wife of the owner of the stela) and his brother Titit sitting on the same lion-legged chair. Underneath the chair of the mother and her son Titit, sits a third son Tii. All the three brothers smell a lotus flower. An offering table piled with offerings separates the eldest son from the rest of his family (Figure 3).

The hieroglyphic texts are inscribed in three different places on the third register:

1-In front of the owner of the stela eldest son: there are two vertical columns describing what he is doing.

2-In front of the mother and the second son: there are four vertical lines bearing their names.

3- Between the legs of the mother and her second son: there is a vertical line illustrating the name of the youngest son sitting under the chair.

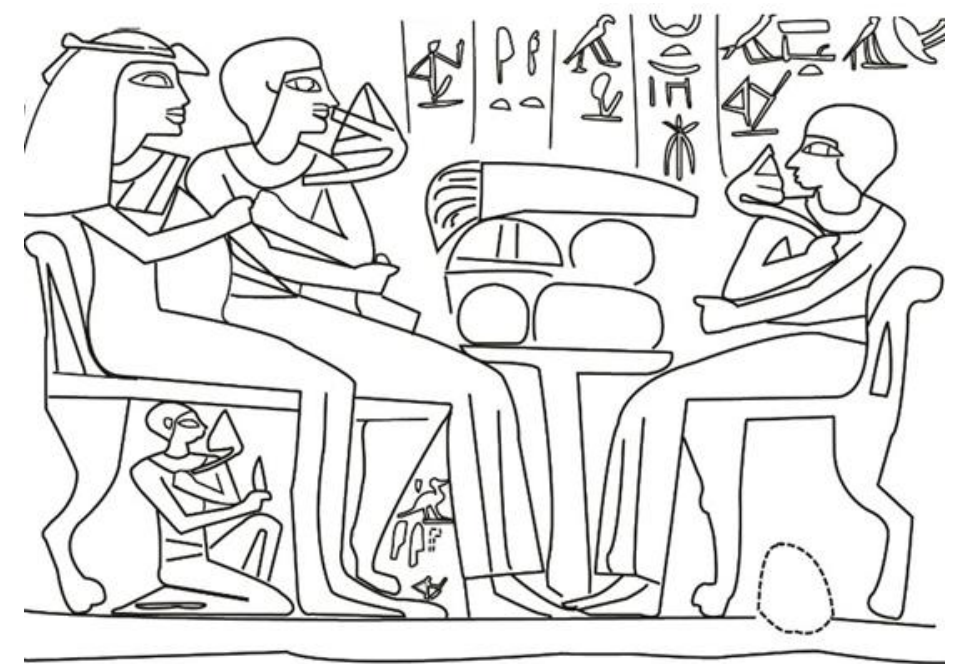

Figure 3.The Third Register 


\section{- THE Eldest SON}

On the right side of the third register, the owner of the stela eldest son, facing left, is seated on a lion-legged chair with a high-backrest, painted in black, in front of a richly laden offering table. He is holding a lotus flower in his right hand up to his nose, while he is resting his closed left fist on his thigh. $\mathrm{He}$ is wearing a short wig covering the ear and the back of the neck, a wide wsh collar and a long tight straight kilt held by a belt. He is resting his bare foot on the ground. The son's skin is painted in reddish-brown whereas his wig, kilt and the lotus blossom are painted in white. Above his head, a horizontal hieroglyphic line can be read as follows:

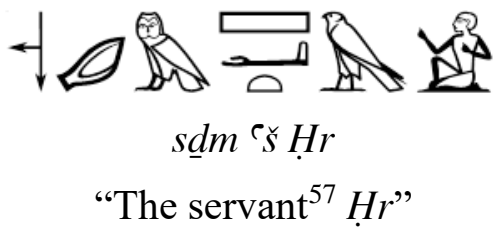

Or it can be translated as before "the call listener $H r$ ". The writer mistook for the second time in writing the word $\square \breve{s}$ before the letter ${ }^{c}$ and then added a $\bigcirc$ unnecessarily (Figure 3).

It is worth mentioning that $\mathrm{Hr} n f r \mathrm{Mnw}$, the eldest son of the owner of the stela, stands in a similar portrayal as his father in the second register, which is a distinguished place compared to the rest of his family. He also held the same title as his father "The servant $H r$ ", which indicates his role in carrying out the same prayers and the same funerary rituals after the death of his father. As for his name $\mathrm{Hr}$, it appeared since the Old Kingdom and continued until the Late Period ${ }^{58}$. It was also written in many ways as follows: A 2 , \& $\stackrel{9}{5}^{59}$. We deduced that $H r n f r M n w$ is the eldest son because he was the one who replaced his dad in the prayers, and because of his mother name as will be explained later.

\section{- The Offering TABLE}

The offering table, depicted in this register, is quite similar in shape to the one in the second register. Its offerings are less than those in the second register, in front of God Osiris. In this third register, the offerings table stacks three rows: the first one contains three loaves of round bread, the

\footnotetext{
${ }^{57} \mathrm{~Wb} 4$ 4, 389.13-390.4; R.O. Faulkner, Concise Dictionary, 259; H. Lesko, Dictionary III, 126.

${ }^{58}$ H. Ranke, Die Ägyptischen, 245.

${ }^{59}$ H. Ranke, Die Ägyptischen, 245.
} 
middle one depicts round and half-round loaves of bread, and the top row bears a bunch of onions (Figure 3 ).

\section{- The Half-Round BRead}

The half-round bread is the only one existing in the third register that does not appear in the second register. The Ancient Egyptian used to bake this bread on pre-heated molds. The ideogram used for the writing of the half round-bread $\triangle t$ is based on the general form of the bread $\triangle^{60}$. Its name $t$ continued being used in the offerings formula htp di nsw throughout the Egyptian History.

In the Middle Kingdom, it was written $\square \theta$, but this has changed during the New Kingdom by adding a sun as determinative $\rightleftarrows_{|,|} R^{61}$. Since bread was important for the deceased in the afterlife, he carefully took it himself as illustrated in Recitation Number a 271 in the pyramids texts. As mentioned in Recitation Number a 589, the bread should also be fresh and not moldy. Because the deceased biggest fear was that some other person would snatch the bread from him, he had to protect the bread from being snatched as stated in Recitation Number c-d 1226. The most fear for him in the other world was not to find bread which forced him to eat his own filth. This was one of the worst fates that may face the deceased ${ }^{62}$. That is why the deceased was keen to have it on his offering table or in his tomb.

Traces of blue and reddish-brown pigments still appear on the offerings and the offering table.

\section{The Wife And Her Two Sons}

On the left of the third register, facing right, opposite to the sitting eldest son; the wife of $N f r M n w$ is sitting with her middle son on the same lionlegged chair with high-backrest, painted in black, in front of the offering table (Figure 3).

The wife of the owner of the stela is wearing a long black wig surrounded by a headband with small aromatic paint composed of a leaf of

${ }^{60} \mathrm{P}$. Kaplony, Die Inschriften der Ägyptischen Frühzeit, III (Wiesbaden, 1963), Taf. 106, no. 517; 33 إيمان محد المهدي، الخبز في مصر القديمة،

${ }^{61}$ Sh. Allam, Hieratische Ostraka und Papyri aus der Ramessidenzeit (Tübingen, 1973), $225-226$.

$$
\text { 62عائشة محمود محمد عبدالعال، لوحات أفراد الدولة الوسطى، 229- } 133 .
$$


a lotus flower $* 63$, a broad wsh collar and a long tight straight ankle-length dress with two straps. Her extended two hands affectionately clap the back and the right arm of her son while her bare foot rests on the ground. Traces of reddish-brown and blue colors still appear on the women's skin, dress and collar.

Seated next to her on the same chair, her middle son is depicted wearing a short wig covering the back of the neck but leaves the ears exposed, a large wsh collar, and a long narrow fitting kilt held by a belt, similar to the one worn by his eldest brother. He is resting his right fist on his clap, while holding a handkerchief. His left hand holds a lotus blossom, sinuously curling away from his body with its blossom looping back towards his nose, giving the impression that he is sniffing its pleasing fragrance. His bare foot rests on the ground. His wig and skin are colored with reddish-brown. Traces of blue color still appear on the lotus flower.

Under the lion-legged chair and specifically under the mother, the youngest son is portrayed on a smaller scale. He sat bending his right knee, while his left leg is bend up. He is drawn in the same appearance like his two brothers. He is wearing a short wig, covering the back of the neck but leaving the ears exposed, a broad wsh collar and a long tight straight fitting kilt held by a belt. As his middle brother, he is resting his right hand on his knee while holding a handkerchief, and bringing with his left hand a lotus flower to his nose (Figure 3).

In front of the wife and her middle son, the hieroglyphic text reads as follows:

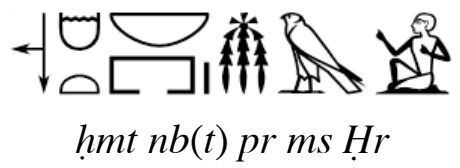

"The wife, the house lady, the mother of $H r$ "

The stela did not mention the name of the mother; she was just called "the mother of $H r$ '. It is a cultural heritage until our days in most of the Egyptian villages where the mother is always called with the name of her eldest son

${ }^{63}$ What proves that this stela goes back to the New Kingdom is that those aromatic cones appeared only since the Eighteenth Dynasty. Those cones appeared ever since the reign of King Amenhotep III, where they regularly appeared topping the heads of the people crossed by the Lotus flower on the front. Sometimes, a huge lotus flower replaces the aromatic cone as in the stela under study. For additional information, see: A. Wiedemann, "Bronze Circles and Purification Vessels in Egyptian Temples", PSBA 23 (London, 1901), 265; A. Hermann, Stelen, 56; E. Staehelin , "Untersuchungen zur Ägyptischen Tracht im Alten Reich", MÄS 8 (Munich, 1966), $113 \mathrm{ff}$. 
(the mother of....). This is another proof that $\mathrm{Hr}$ is the eldest son as discussed before.

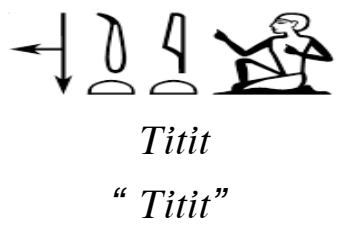

This is the middle son name. This name continued to appear from the Middle Kingdom until the end of the Late Period ${ }^{64}$.

Between the legs of the mother and her son, the text is as follows:

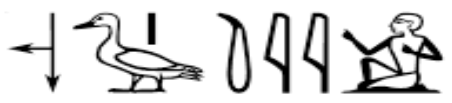

s3 Til

"The son Tỉ"

This is the name of the youngest son sitting under the chair. This name appeared in the Middle Kingdom and continued to exist until the Late Period $^{65}$.

\section{CONClusion}

-The artistic features of the stela indicate that $N f r M n w$, the owner of the stela, is a nobleman of the New Kingdom, despite that his title is not mentioned.

- Currently in most Egyptian villages, the mother is always called with the name of her eldest son (the mother of....). This cultural heritage sustained from the Pharaonic Period until now. The proof is that this stela did not mention the name of the mother (wife of $N$ fr $M n w$ ), but she was referred to as "the mother of $H r$ ", who is her eldest son.

- Hr Nfr Mnw is the eldest son of $N f r M n w$ because he was the one who replaced his dad in the prayers, and because of his mother name was stated as "the mother of $\mathrm{Hr}$ ".

${ }^{64}$ H. Ranke, Die Agyptischen, 378. For more information for its appearance in the Middle Kingdom, see: BM 207, JE 20186 I, 20715 D; F. Petrie, Illahun, Kahun and Gurob 1889- 90 (London, 1891), TF. 12,14. For more information about its appearance in the New Kingdom, see: A. Kamal, "Chapelle d' un mnevis de ramses III", RT 25 (Le Caire, 1903), 35.

${ }^{65}$ H. Ranke, Die Agyptischen, 1, 377; E. Schiaparelli, Museo Archeologico, 1541. For more information about the name in the New Kingdom, see: Berlin 7282, JE 20035; K. Sethe, Urkunden der 18. Dynastie, 4 (Leipzig, 1909), 135, 2; J.J. Tylor, and F.Li. Griffith, The Tomb of Paheri at El-Kab (London, 1894), TF. 7, BM 158. 
- The stelae depicting on its lunette a sun-disk with a single wing balanced by a single $W \underline{d} 3 t$ eye always portray an individual in whose memory the stela was erected or who was himself the donor of it.

-The single wing of the sun-disk is always represented as extending over the divinities, whereas the sacred eye is over the worshipper.

-The depiction of the sun-disk with one wing beside the $W \underline{d} 3 t$ eye may indicate the completion of the eternal light during the day by the sun that is represented by the sun-disk and during the night by the moon, which is represented by the eye of $W \underline{d} 3 t$. The winged sun-disk with the $W \underline{d} 3 t$ eye represent the daily cycle for the sun; ie: the cycle of renewal and resurrection represented in the sunrise and the sunset of the sun. Thus, portraying the sun-disk with the $W \underline{d} 3 t$ eye on the stela ensure for him protection, renewal and life as well as being an important element of lighting.

- This stela dates back to the New Kingdom, because of the following:

- The style of the cloths and wigs is consistent with the New Kingdom.

- The lunette of the stela portraying a sun-disk with a single wing beside the $W \underline{d} 3 t$ eye is a style that goes back to the Eighteenth Dynasty between the reigns of Kings Amenhotep I, III.

- The aromatic cones topping the heads of the people (sometimes replaced by a huge lotus flower as worn by the wife of the owner of our stela) appeared only since the Eighteenth Dynasty as it emerged since the reign of King Amenhotep III. This confirms that this stela dates back to the New Kingdom, especially during the reign of King Amenhotep III.

- The sculptor of the stela seems to be a beginner, not a professional, as he engraved the signs in a very simple way with many mistakes:

- In the second register, the text in front of the face of the owner of the stela Nfr Mnw:

- The artist carried out the painting after completing the etching of this inscription: the text was etched in three vertical hieroglyphic slanted columns in sunk-relief, and, afterwards, the artist painted three straight red vertical lines, supposedly to correct the slanting of the inscribed text.

- The direction of the sign $\triangle$ di in the word $\frac{\Delta}{\Delta}$ rdit is opposite to the direction of the rest of the text.

- The direction of the signs of the word $\Delta ? h k$ s is opposite to the direction of the rest of the signs of the text. 
- In the second register, the text in front of the foot of the owner of the stela Nfr Mnw and under the offering table:

- The writer mistook in writing the word

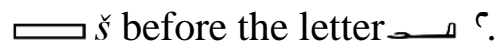

- In the third register, the text in front of the son $\mathrm{Hr} N \mathrm{Nr} M n w$ :

- The writer mistook for the second time in writing the word he wrote again the letter $\longleftarrow \breve{s}$ before the letter ${ }^{c}$ and then added a $\square t$ unnecessarily.
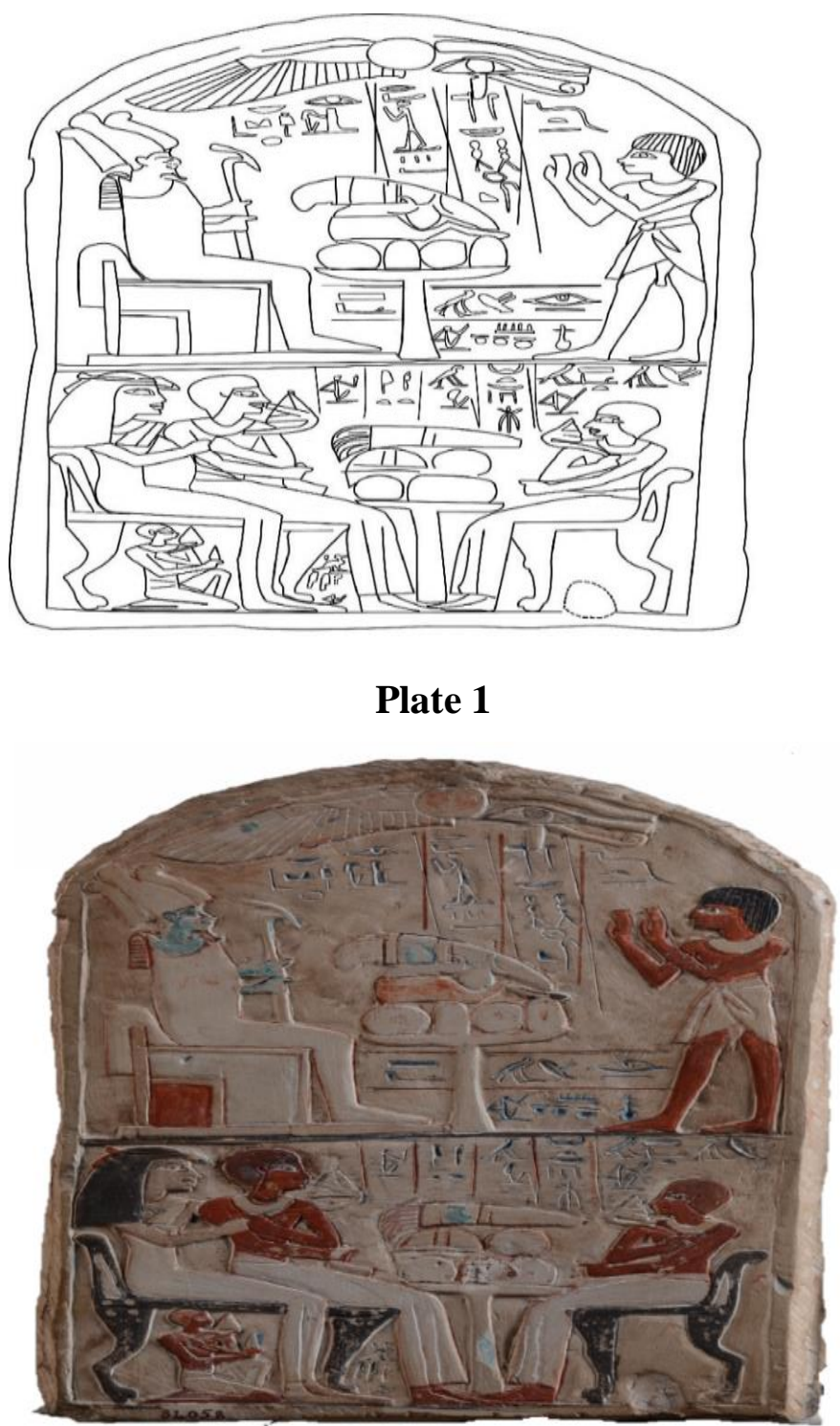

Plate 2 


\section{REFERENCES}

A. Badawi and H. Kees, Handwörterbuch der Ägyptischen Sprache, I (Cairo, 1958).

A. Badawy, "La stèle funéraire sous l'ancien empire: son origine et son fonctionnement", ASAE 48 (Le Caire, 1948).

A. Erman, “Zu Namen des Osiris”, ZÄS 46 (Leipzig, 1910).

A. Gardiner, The Inscriptions of Sinai (London, 1955).

A. Hermann, "Die Stelen der Thebanischen Felsgräber der 18 Dynastie", ÄF 11 (Glückstadt, 1940).

A. Kamal, “Chapelle d'un mnevis de ramses III", RT 25 (Le Caire, 1903).

A. Mariette, Catalogue Général des Monuments d'Abydos Découverts pendant les Fouilles de cette Ville, (Paris, 1821-1881).

A. Radwan, “The Stela Louvre C 211”, BACE 21 (Sydney, 2010).

A. Radwan, "Zur Stellung des Königs in der Zweiten Zwishenzeit", in: Festschrift Jürgen von Beckerath, HÄB 30 (Hildesheim, 1990).

A. Wiedemann, "Bronze Circles and Purification Vessels in Egyptian Temples", PSBA 23 (London, 1901).

A.E. Weigall, “An Ancient Egyptian Funeral Ceremony”, JEA II (London, 1915).

A.J. Spencer, Death in Ancient Egypt (New York, 1984).

A.M. Roth, "Fingers, Stars, and the Opening of the Mouth: The Nature and Function of the ntrwj-Blades", JEA 79 (London, 1993).

A.O. Bolshakov, "Offering Tables", OEAE II (Oxford, 2001).

Ch. Leitz, Lexikon der Ägyptischen Götter und Götterbezeichnungen, Band V (Leuven, 2002).

D. Samuel, "Bread", in: D. Redford (ed.), The Oxford Encyclopedia of Ancient Egypt, I (Cairo, 2001).

D. Wildung, “Flügelsonne”, in: LÄ II (Wiesbaden 1977).

E. Schiaparelli, Museo Archeologico di Firenze (Roma, 1887).

E. Staehelin, "Untersuchungen zur Ägyptischen Tracht im Alten Reich", MÄS 8 (Munich, 1966).

F. Petrie, Illahun, Kahun and Gurob 1889- 90 (London, 1891). 
Fr. Preisigke, Wörterbuch Dergriechischen Papyrusurkunden (Berlin, 19251931).

G. Maspero, Études de Mythologie et d'Archéologie Égyptiennes, IV (Paris, 1912).

G. Maspero, Guide to the Cairo Museum (Cairo, 1908).

G. Reisner, The Development of the Egyptian Tomb down to the Accession to the Cheops (Cambridge, 1936).

H. Frankfort, Ancient Egyptian Religion (New York, 1949).

H. Junker, Gîza, III (Wien-Leipzig, 1938).

H. Lesko, A Dictionary of Late Egyptian, III (Berkeley, 1987).

H. Ranke, Die Ägyptischen Personennamen, Bd. 1: Verzeichnis der Namen (Glückstadt, 1935).

H.H. Nelson, H. Leichter, A. Bollacher and S. Schott, Medinet Habu. 3: The Calendar, The Slaughterhouse, and Minor Records of Ramses III (Chicago, 1934).

J. Vandier, Manuel d'Archéologie Égyptiennes, I (Paris, 1952).

J.J. Tylor, and F. L. Griffith, The Tomb of Paheri at El-Kab (London, 1894).

J.W. Wegner, "Osiris", in: D. Redford (ed.), The Oxford Encyclopedia of Ancient Egypt, I (Cairo, 2001).

K. Martin, "Stele”, in: LÄ VI (Weisbaden, 1986).

K. Sethe, Urkunden der 18. Dynastie, 4 (Leipzig, 1909).

K.P. Kuhlmann, “Der Throne im Alten Ägypten”, MDAIK 10 (CairoBerlin, 1977).

L. Bull, "Two Egyptian Stelae of the XVIII Dynasty", Metropolitan Museum Studies, Volume 2, Part 1 (Cairo, 1929).

M. Mostafa, "Ntersuchungen zu Opfertafeln im Alten Reich", HÄB 17 (Hildesheim, 1982).

M.L. Bierbrier, Historical Dictionary of Ancient Egypt, in: Historical Dictionaries of Ancient Civilizations and Historical Eras, I (Lanham, 1999).

P. Kaplony, Die Inschriften der Ägyptischen Frühzeit, III (Wiesbaden, 1963).

P. Wilson, A Ptolemaïc Lexicon. A Lexicographical Study of the Ptolemaïc Texts in the Temple of Edfu (Leuven, 1997). 
R. Hölzl, "Giebelfelddekoration von Stelen des Mittleren Reiches", in: Beiträge Zur Ägyptologie 10 (Wien, 1990).

R. Hölzl, "Round-Topped Stelae from Middle Kingdom to the Late Period, Remarks on the Decoration of the Lunettes", SCIE 1 (Wien, 1992).

R. Hölzl, "Stelae", in: D. Redford (ed.), The Oxford Encyclopedia of Ancient Egypt, III (Cairo, 2000).

R. Wilkinson, Reading Egyptian Art (London, 1992).

R.O. Faulkner, Concise Dictionary of Middle Egyptian (Oxford, 1962).

S. Hassan, Excavations at Giza, Volume VI, Part II (Cairo, 1984).

Sh. Allam, Hieratische Ostraka und Papyri aus der Ramessidenzeit (Tübingen, 1973).

T. Handoussa, "Le Collier Ousekh", SAK 9 (Hamburg, 1981).

T.G. James, The Mastaba of Khentika Called Ikhekhi (London, 1953).

W. Westendorf, "Altägyptische Darstellungen des Sonnenlaufes auf der Abscüssigen Himmelsbahn”, MÄS 10 (Munich, 1966).

Y. Muckiki, "On the Transliteration of the Name of Osiris", JEA 76 (London, 1990).

أحمد أنور عبد المهيمن، دراسة لموائد وأحواض القرابين بالمخزن المتحفي بالأشمونيين، رسالة

$$
\text { ماجستير غير منشورة (جامعة المنيا: كلية الآداب، 2019). }
$$

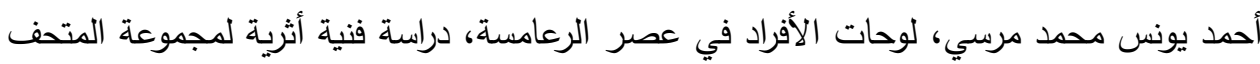

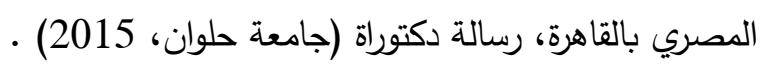

إيمان محمد المهدي، الخبز في مصر القديمة حتى نهاية الدولة الحديثة، رسالة ماجستير غير

$$
\text { منشورة (جامعة القاهرة: كلية الآثار ، .99 (1)). }
$$

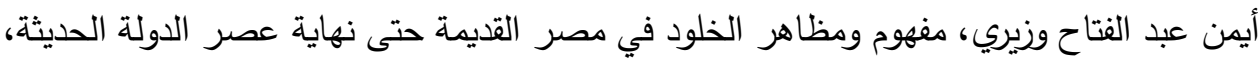
رسالة دكتوراة غير منشورة (كلية الآثار: جامعة القاهرة، 2004).

خالد الطلي، أهم موائد قرابين منطقة الصوة بمتحف هرية الرزنة، المجلة العلمية اتحاد الآثاريين

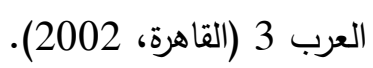

روبير جاك تيبو، موسوعة الأساطير والرموز الفرعونية، تعريب: فاطمة عبد الله محمود (القاهرة:

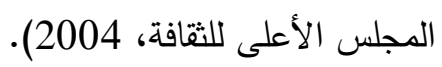

سيريل الدريد، الفن المصري القديم (القاهرة: الهيئة العامة للكتاب، 1990). 
سيلفي كوفيل، قرابين الآلهة في مصر القديمة، تعربب: سهير لطف الله (القاهرة، 2010). عائشة محمود عبد العال، لوحات أفراد الدولة الوسطي (مجموهة المتحف المصري بالقاهرة)، رسالة ماجستير غير منشورة (كلية الآثار : جامعة القاهرة، 1995).

عائشة محمود عبد العال، لوحة إيري سبك بالمتحف المصري بالقاهرة رقم JE $91726 ،$

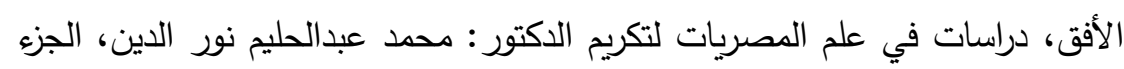

$$
\text { الأول (القاهرة 2009). }
$$

ماسيمولاني فرانشي، الفلك في مصر القديمة، تعربب: فاطمة فوزي- أنس إبراهيم- علاء شاهين، الطبعة الأولى، (القاهرة: المركز القومي للترجمة، 2015).

مراد علام، قرص الثمس (المجنح) ذو الجناح الواحد وعين الودجات على قم اللوحات، عالم

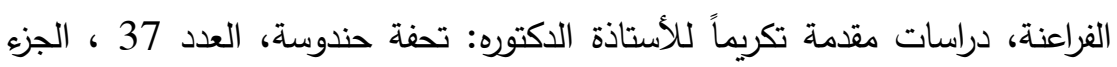

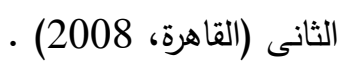

